\title{
Quotation as a Text-Forming Element
}

\author{
Abdullayeva Khayala Ramiyyadin ${ }^{1}$ \\ ${ }^{1}$ Ganja State University, Ganja, Azerbaijan \\ Correspondence: Abdullayeva Khayala Ramiyyadin, Ganja State University, Ganja, Azerbaijan. E-mail: \\ khayala@yahoo.com
}

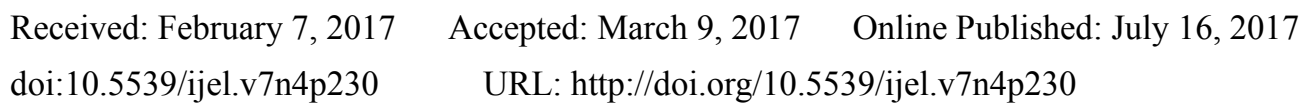

\begin{abstract}
Text (either literary or scientific) is one of the greatest units which is formed through the relationship of formal and semantic factors. It also denotes completeness of texts which forms systems of semantics, logic, pragmatic aspects. Each of the factors which is used to form the completeness of the texts has a very crucial role as well as the quotation. Quotations are considered to be main means which provide the formal-structural and logical-semantic completeness of the texts. The textforming functions of the quotations as well as its functionalism have been investigated in the article.
\end{abstract}

Keywords: text, quotation, textforming, linking, cohesion, cognitive, relationship

\section{Introduction}

Once Aristotel gave explanation to the term "text", and it insistently keeps its meaning nowadays: "Text means completeness, and it has its beginning, middle and end paragraphs" (Aristotle, 1984, p. 32). Some scientists claim that text hasn't been investigated widely in Azerbaijani linguistics.

The term "text" means connection in Latin. It means that there should be strong connection between the elements of the texts.

There are different minds about texts consisting of two sentences. That is why some scientists can consider sentence as a text. But there is one point that is needed to be paid attention too. As sentences are framed by structural-semantic lines a text is wider than a sentence.

Text is a verbal record of a communicative event (Gillian, 1983, p. 190). It has widely been investigated by different linguists of the world such as Teun A. van Dijk, R.de Beaugrande, M. A. K. Halliday \& R. Hassan, etc. The mentioned authors studied the principles of connectivity in the texts. And they claim that connectivity binds a text together and forces co-interpretation. Halliday \& Hasan state that sentences either form a text or not. They denote cohesive relationships within and between the sentences; in the result texture is created. They write: "A text has texture and this is what distinguishes it from something that is not a text... The texture is provided by the cohesive relation (Halliday, 1976, p. 2).

Moreover, according to their viewpoint cohesive relationships within a text are set up where the interpretation of some element in the discourse is dependent on that of another. The one presupposes the other in the sense that it cannot be effectively decoded except by recourse to it (Halliday, 1976, p. 4). The following example can illustrate the meaning.

Please take some pears, and put them into the plate.

In the second sentence the pronoun them has an anaphoric meaning, and it gives cohesion to the two sentences. As a result we can interpret them as a whole; together the sentences constitute a text. It is noteworthy to state that Halliday and Hasan highlights a taxonomy of types of cohesive relationships which can be formally established within a text, providing cohesive "ties" and they can bind a text together.

\section{Literature Review}

Text forms special avtomon structure in a general structural mechanism. It is considered to be denoting a complete thought in the line of sentences from the lower lines to the highest lines. All complete thoughts can be described in marcotexts, though microtexts consists the main body of the macrotexts.

Besides, text is a kind of sending information of the constructions that have relations among themselves. 
Like hyponymy, collacability, by further structural relationships like causal substitution, comparison, by syntactic repetition, by consistency of tense, by stylistic choice, etc. cohesion can be derived from lexical relationships. Let's take an example from Marina warner's Queen Victoria'a Sketchbbok:

Lord Melbourne, who was Prime Minister when Victoria became Queen in 1837, did not like birdsong and could not distinguish woodlark from a nightingale. He preferred the singing of blackbirds anyway; best of all he liked the cawing of rooks and could watch them for hours as they circled at sunset. Victoria was surprised by this: she disliked their granting and insistent calling.

Lord Melbourbe refers to-Prime Minister-he-he

Victoria refers to-Queen-Victoria-she

Rooks - them-they - their.

The following lexical quotations can be observed:

1) Birdsong — woodlark-nightingale-blackbirds - rooks

2) Birdsong-singing-cawing-calling

There are also some additional markers too such as anyway can be used as adversative marker, preferred, best of all as comparison, "Victoria was surprised by this" can be used as a pronominal expression referring back to the content of the previous clause, and it can be considered as consistent tense and repeated negative structure. The role of punctuation marks shouldn't be forgotten. In the given extract the punctuations semi colon (;) and dot (.) indicate a relationship between what has been said and what is about to be said. They perform the function of as verbal markers of conjunctive relation act.

The other way that the scientists studied was to investigate cohesion can guarantee indentification as a text. In this case the constituted collection of sentences can be interpreted or not. The following passage can give us a chance to illustrate our opinion:

[1] A man in white clothes, who could only be the surviving half-breed, was running as on does run when Death is the pace-maker. [2] They white figure lay motionless in the middle of the great plain. [3] Behind him, only a few yards in his rear, bounded the high ebony figure of Zambo, our devoted negro. [4] An instant afterwards Zambo rose, looked at the prostrate man, and then waving his hand joyously to us, came running in our direction. [5] They rolled on the ground together. [6] Even as we looked, he sprang upon the back of the fugitive and flung his arms round his neck. (The passage was taken form Sir Arthur Conan Doyle's The Lost World. 1912)

As it is seen formal cohesion is not guarantee the identification of a text; it only guarantees textual coherence.

If this text is tried to be reconstituted without the original sentence-order arrangement, then there are some formal expressions of cohesive relationships may be needed. But in this case a reader may also try to form a coherent picture of the series of events that having been described and the described facts should fit the events together. It is not needed to work with the verbal connections separately. Enkvist explains it as "textness" and states that such inadequacy of cohesive ties across sentences as the main source of guarantee (Enkvist, 1980, p. 1978). He (Enkvist) gives such an example:

I bought a Ford. A car which President Wilson rode down the Champs Elysees was black. Black English has been widely discussed. The discussions between the presidents ended last week. A week has seven days. Every day I feed my cat. Cats have four legs. "The cat is on the mat. Mat has three letters."

One fact attracts our attention. Enkvist claims that in the extract there is a "semblance" of cohesion such as Ford-car, black-Black, my cat-cats. Here types of connection can be observed. But unlike Enkvist Brown and Yule call such kind of sentences as a coherent text.

Lyons also considers a text as a sequence of sentences. In this point some can agree with Lyons as some texts would satisfy the stated definition. Although there are some kind of sentences that some texts are made up of a mixture of sentences, sentence-fragments and ready-mady locutions. Lyons claims that this can be understood as the defect in the definition of a "text" (Lyons, 1995, p. 260). The definition that was given by Lyons clarifies only one side of a more serious deficiency. Its failure is seen in the units of which a text is composed.

The difference between form and content has to do with the difference to distinct the properties of cohesion and coherence. The following examples can illustrate the theory. For instance, "I have not seen Mary" the sentence should have the form I haven't than I have not seen Mary is a kind of cohesion. It the three sentences can be put in different order then cohesion is destroyed: 
Peter hasn't either. I haven't. Have you seen Mary?

If each of the text-units can be replaced with the corresponding full text-sentences, cohesion is also destroyed such as:

Have you seen Mary? I haven't seen Mary. Peter hasn't seen Mary (either). Mary is never here when she should be here.

It is seen that these sentences don't have the same kind of connectedness as the first ones.

Ellipsis and the use of pronouns, also the use of particular connecting particles and conjunctions such as therefore, so, and others are used to serve to create that kind of connectedness to which the term "cohesion" is applied.

Coherence is also used to serve to distinct the other kind of connectedness.

Lately, the points how the text have been created by the means of language have been investigated. The role of ellipsis, repeatitions, terms, phraseology, etc. have been touched upon in creating texts. The quotation also plays a very crucial role in creating texts. Of course, texts can be created without quotations too. For the first point, it is noteworthy to mention that quotation plays a very important role in sending the information, and catching the reader's or listerner's attention. For instance, let us analyse the following quotation: "Baku is a center of an oil industry. In the late XIX century Baku was in its development of oil industry, and there also existed some defects in the production of the oil according to capitalism rules". This extract was taken from T. Hacijev's speech. Reading this quotation a reader, or listener may be aware of the development and current status of the oil industry in Azerbaijan. Moreover, the defects of the development of an oil industry depending on the period of capitalism were also put forward to the reader. A reader whether an outsider or a native one doesn't hesitate to create an idea on his/her head about the Azerbaijani's oil industry.

If needed the author of the quotation cannot be mentioned. "A general situation, connecting to the situation and context and if the indirect address of the speaker is known then quotation is not used. (Kazimov, 2008, p. 474)

This quotation has been created like a simple extended. There are ways that the author of the quotation can be kept unknown. For example, "I began learning the Azeribaijani language. When it is necessary to learn French in Europa, then it is necessary to learn Azerbaijani in the Caucasus. Generally, it is necessary to learn this language in Asia". This quotation was taken from the letter which was written by MY. Lermontov to his friend S. A. Rayevski. It is noteworthy to state that repetitions, word order; particles, modal words, pronouns, formal means such as units of synomus; connectiveness, uniqness, etc. play very important role.

Each quotation that is given by the author serves its own purpose in the text. Quotation is used when the author wants to mention, something, or give additional information about something for enlarging the text.

\section{Methods}

Quotations can also be given as an example for forming a text in the structural aspect. It is known that while creating the text quotations are related to a strong base. Quotations have cognitive functions as well.

Uniqueness is also considered to be an important factor in the texts. Repetition has the character of isolation, and it serves as an inside language unit of a text. It connects the sentences inside a text as a connector. Overall, the frequency of service for the organization of the text is a sign of self-recurring impact of the sentence, and it becomes more and more integrated element of the structure which loses its independence of a certain extent, as the structure of the text.

The relativeness of the meaning is also very important. It (the relativeness of the meaning) is balanced between the sentences in the quotations and between the sentences in the main text. For instance, the meaning relativeness is observed in the main text and in the quotation text:

"A person's daily life, ethnography, thinking, activities directly related to the phraseology expressions, as well as being common to all languages, national character, the formation, the formation of the domestic laws of each language and its framework is based on its system".

The quotation text that follows it: "Phraseology is considered to be unique either for Russian or for any other languages. The existence of the language, the inside laws of the language, and its mational features are clearly described here".

Some scientists claim that the quotations in some scientific texts bring definiteness to the indefiniteness in the main texts. For instance, the term of "the dictionary of orphophony" has been brought to the Azerbaijani linguistics by Veysalli. In the preface of the dictionary it is written: "Orphophony studies the pronunciation 
features of the encountering phonology in the language and their realization in speech".

The quoatation that was written after this sentence serves to define the indefiniteness in the text: "Unlike orphoepia, the scientific branch that studies the changings which are observed in a certain phonetic position beside the various phonemes, and under the influence of stress and intonation is called orphophonia".

Like other text forming factors, quotations also carry a complex text forming character. Quotation is functioned among the components of the text. It forms a new meaning source, and demands that the opinion should be developed in the text. Quotations perform a lot of cognitive functions such as summary, background, problem-exposure, tool-orientation, understanding exposure, argumentative, forecasting, etc. in the texts. Abdullayev writes about quotation: "Quotation plays a very important role in a text forming. They have an expansion character, and it is considered as an inside unit of the text". The lexical units inside the text are very various. In the Azerbaijani language quotations can be used in all paragraphs. For instance, "Bayaqdan yekə görünən balıqlar indi balacalaşmışdır, büzüşmüşdür. Yəqin ona görə belə idi ki, balıqlar sudan çıxanda hələ ölməmişdilər. Ürəkləri, ciyərləri sağıydı. İndi isə onları keçirmişdir haça ağaca. Bir-bir götürüb qoyurdu im-isti torpağa və sığallaya-sığallaya sayırdı. Balıqları əlində o qədər gəzdirmişdir ki, yulğun kollarına dəyməkdən pulları tökülmüş̧ür və elə bil ki, döyülmüş̧ür. Tez-tez balıqları suya salıb çxardırdı və onda balıqlar az da olsa yəkəlirdilər" (The quotation was taken from "Nisgil" by Elchin Huseynbeyli, 1993, p. 151).

Dressler writes: "Actual linking and the formation of the texts are related with each other through quotations in some way". According to this scientist quotations are considered to be the connectors of the paragraphs inside the texts." (Dressler, 1978, p. 125). The following example can illustrate our viewpoint: "Thirty years ago in literary circles God was all the fashion. That was a good form to believe and journalists used him to adorn a phrase or balance a sentence: then God went out (oddly enough with cricket and beer) and Pan came in (S. Maugham).

\section{Discussions}

Each text is used to concern determining the relationship between the speaker and the utterance. In this case there should be some connectiveness among the sentences that create the text. The usages of these linguistic terms such as reference, presupposition, implicature, inference have an important role for creating the completeness the text.

Lyons states "the relationship which holds between words and things is the relationship of reference: words refer to things" (Lyons, 1995, p. 28). The relationship between a language and a world is observed in this linguistic unit. Lyons also adds: "It is the speaker who refers (by using some appropriate expression): he invests the expression with reference by the act of referring" (Lyons, 1977, p. 177). Yet, Strawson makes the following point "referring" is not something an expression does; it is something an expression does; it is something that someone can use an expression to do (Strawson, 1952, p. 56). Searle puts his point of view about the problem like this: “...in the sense in which speakers refer, expressions do not refer any more than they make promises or give orders' (Searle, 1979, p. 155). It means that in texts reference is treated as an action on the part of the speaker, or writer.

Reference is considered to be an action on the part of the speaker, or writer in the texts. For example, A: my cousin is coming home from England on Saturday + she is due in +

B: How long has she been away for or has he just been away?

A: I have to say that they lived in England, now they are returning.

In this extract my cousin and she may refer to one individual and my uncle's daughter and she to refer to another.

Presupposition also has a role in context. In the above mentioned example the speaker A gives the information that she has a cousin as presupposed and the speaker B, indicates that she has accepted this presupposition. Givon writes about it: "defined in terms of assumptions the speaker makes about what the hearer is likely accept without challenge" (Givon, 1979, p. 50). The notion of assumed "common ground" is also involved in such a characterization of presupposition and Stalnaker mentions about it in his speech: "presuppositions are what are taken by the speaker to be the common ground of the participants in the conversation (Stalnaker, 1978, p. 321). It is necessary to highlight that the speaker is considered to be the source of presupposition in the quotations. The notion of logical presupposition is described by Keenan like this:

A sentence $\mathrm{S}$ logically presupposes a sentence $\mathrm{S}$ just as in case $\mathrm{S}$ logically implies $\mathrm{S}$ and the negation of $\mathrm{S}, \sim \mathrm{S}$, also logically implies S. (Keenan, 1971, p. 45)

Brown \& Yule state their point of view like the following: 
a. My cousin is coming home from England.

b. My cousin isn't coming home from England.

c. I have a cousin.

G. Brown and G. Yule states that according to Keen's definition (a) logically presupposes (c) because of constancy under negation.

Givon uses the term "implicature" for to account for what a speaker can imply, suggest, or mean, as distinct from what the speaker literally says. Grice distinguishes conventional implicatures which are determined by "the conventional meaning of words" (Grice, 1975, p. 44). Brown and Yule emphasise the fact that implicatures are pragmatic aspects of meaning and have certain identifiable characteristics.

According to Hanks referential and predicational act types can be considered to compose the meaning of a sentence.

The following quotation may illustrate our point of view:

In these offices people do not gather like a common crowd, there make some relationship among them such as the political, moral relationship can be observed among them. Such kind of communication is used to activate the social duty of a language and gives it to be complete. Besides, the communication with the deligation of different nations such as Russians, Georgians, etc. help the nations of Azeris to develop their literary language skills, and gives them ability to rise the language norms. Then the author (T. Haciyev) mentions the quotation of F. Khocherli: "Whatever philosophy may be a certain Russian scientist any Russian peasant can understand his language...."

Connectiveness also plays a very crucial role in creating the content of the text, and forms its logical-semantic completeness. Abdullayev writes: "Pharagraphs have strong systems which have been formed through formal and semantic relationship of texts". It means that the factors which provide the meaning relationship between the components are closely connected with the factors which provide the structural relationship between the components of texts. (Abdullayev, 2012, p. 508)

Among the relationships of the quotations logical-semantic-syntactic connectiveness can be observed. The relationship between the types of provisions as defined in the mind corresponds the same methods.

Solqanick writes about it: "The types of provisions that are created in the mind have relationship with the previous repititions, or they can be observed in the next repitions. In this case the predicate in the previous provision becomes subject, and the subject in the next provision becomes predicative. This method forms the chain relationship in texts. In the parallel relationship the words which are repeated in the provisions have the same functions. They can function as a predicate or as a subject either in the previous sentence or in the next one (Solqanick, 1973, p. 21).

The following example can be given as an example to the chain relationship:

I have been thinking about this problem since morning. I have been thinking that "every man should deserve his service". This quotation has developed through chain relationship.

The very relationship of components begins (have been thinking-have been thinking) with the development of the predicate in the previous text. The predicate of the previous component makes the text the base of logical-semantic sourse of the whole text. The quotation that is used in the second component not only connects the sentences but also delivers the addresser's opinion to the reader or the listener. It means that the author asks the reader's or listener's opinion about it?

\section{Conclusion}

Text covers both a language and a speech activity. As being language act, it includes invariant content, but the speech act also includes invariant content too. The completeness of the content, the relationship among its components all are created by the use of quotations in it. The language scinery is related to the semantic, structural, and communicative principles and these aspects have importance not only from their linguistic point, but also from semantic, philosophical-ontological point.

The coherent completeness of the text includes quotation; logical-poetic completeness includes cognition, and all of these are related to the levels of the quotations such as a) the syntactical level, b) the pragmatic level, and c) the semantic level. There are four plans of the relationship of the text with the quotation. They are the semantic plan, the syntactic plan, the pragmatic plan, and the functional plan. All of these plans take part in forming the completeness inside the text. 


\section{References}

Abdullayev, K. M., \& Mammadov, A. Y. et al. (2012). The complex paragraphs in the Azerbaijani languages. Baku: Mutarim Publishing House.

Aristotle. (1984). Composition. Moscow: Moscow Publishing House.

Brown, G., \& Yule, G. (1983). Discourse Analysis. Cambridge: Cambridge University Press. https://doi.org/10.1017/CBO9780511805226

Enkvist, N. E. (1980). Coherence, pseudo-coherence, and non-coherence. In J. O. Östman (Ed.).

Givon, T. (Ed.) (1979). Syntax and Semantics, 12: Discourse and Syntax. New York and London: Academic Press.

Grice, H. P. (1975). Logic and conversation. In P. Cole \& J. Morgan (Eds.), Syntax and Semantics 3: Speech Acts. New York: Academic Press.

Halliday, M. A. K., \& Hassan, R. (1976). Cohesion in English. London: Longman.

Kazimov, G. (2008). Selected works (Vol. 5). Baku: Nurlan Publishing House.

Keenan, E. L. (Ed.). (1971). Two kinds of presupposition in natural language. In C. J. Fillmore \& D. T. Langendoen (Eds.), Studies in Linguistic Semantics. New York: Holt, Rinehart and Winston.

Lyons, J. (1995). Linguistic Semantics. Cambridge: Cambridge University Press. https://doi.org/10.1017/CBO9780511810213

Searle, J. R. (n. d.). Expression and Meaning. Cambridge and New York: Cambridge University Press.

Solqanick, T. Y. (1973). The Syntactical stylistics. Moscow: Moscow Publishing House.

Stalnaker, R. C. (1978). Assertion. In P. Cole (Ed.).

Strawson, P. F. (1952). Introduction to Logical Theory. London: Methuen.

\section{Copyrights}

Copyright for this article is retained by the author(s), with first publication rights granted to the journal.

This is an open-access article distributed under the terms and conditions of the Creative Commons Attribution license (http://creativecommons.org/licenses/by/4.0/). 